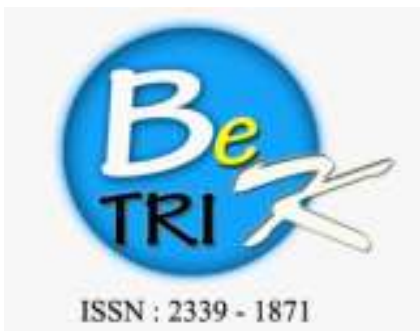

JURNAL ILMIAH BETRIK

Editor Office : LPPM Sekolah Tinggi Teknologi Pagar Alam, Jn. Masik Siagim No. 75 Simpang Mbacang, Pagar Alam, SUM-SEL, Indonesia Phone : +62 852-7901-1390.

Email : betrik@lppmsttpagaralam.ac.id / admin.jurnal@lppmsttpagaralam.ac.id Website : hrtps://ejournal.lppmsitpagaralam.ac.id/index.php/betrik/index

\title{
PERANGKAT LUNAK BANTU PENDAFTARAN KREDIT PEMILIKAN RUMAH (KPR) PADA PT. BAITI SEJAHTERA BERBASIS WEB
}

\author{
Sasmita \\ Dosen Sekolah Tinggi Teknologi Pagar Alam \\ Jln. Masik Siagim No. 75 Simpang Mbacang Dempo Tengah Kota Pagar Alam \\ Sur-el:sasmitha661@gmail.com
}

\begin{abstract}
Abstrak: Sistem Pendaftaran Pengambilan dan Pengisian Dokumen Formulir data calon kosumen pada PT. Baiti Sejahtera Pagar Alam, sudah terkomputerisasi namun masih menggunakan aplikasi yang sederhana, Permasalahan yang akan dipecahkan dalam penelitian ini adalah "Bagaimana cara pembuatan Perangkat Lunak Bantu Pendaftaran Kredit Kepemilikan Rumah (KPR) pada PT. Baiti Sejahtera Pagar Alam berbasis Web serta pengolahannya dengan menggunakan PHP dan MySQL " Dalam penelitian ini metode pengembangan yang digunakan adalah Metode Web Engineering (Rekayasa web) yang terdiri dari komunikasi, perancangan, pemodelan, kontruksi dan deployment. Hasil yang didapatkan dalam penelitian ini adalah Perangkat Lunak Bantu Pendaftaran Kredit Kepemilikan Rumah (KPR) pada PT. Baiti Sejahtera Pagar Alam berbasis Web.
\end{abstract}

Kata kunci: Web, KPR, php, Mysql

Abstract: Registration System for Filling and Filling Documents Form of prospective consumer data at PT. Baiti Sejahtera Pagar Alam, has been computerized but still uses simple applications, the problems that will be solved in this study are "How to make Software Help Register Home Ownership Loans (KPR) at PT. Baiti Sejahtera Pagar Alam is Web-based and is processed using PHP and MySQL. "In this research the development method used is the Web Engineering Method (web engineering) which consists of communication, design, modeling, construction and deployment. The results obtained in this study are Software Help Registration of Home Ownership Loans (KPR) at PT. Baiti Sejahtera Pagar Alam Web-based.

Keywords: Web, KPR, php, Mysql

\section{PENDAHULUAN}

Teknologi Informasi menempati peranan utama dalam kehidupan masyarakat sekarang ini dan perkembangannya sangat pesat sekali, karena dengan teknologi informasi kita dapat mengolah dan mendapatkan informasi dengan cepat, tepat dan akurat. Saat ini sudah menjadi kebutuhan bahwa sistem komputerisasi dapat memberi kemudahan dalam mencari informasi yang diinginkan, mengurangi terjadinya kesalahan yang disebabkan oleh kelalaian manusia dan keamanan data pun lebih terjamin, penggunaan komputer dan sistem informasi yang optimal dalam sebuah instansi/perusahaan akan menunjang efisiensi 
dan efektifitas kerja dalam mengolah data untuk mendapatkan informasi yang dibutuhkan.

Rumah merupakan kebutuhan primer bagi manusia sebagai tempat tinggal dan menetap. untuk bisa memiliki rumah, kita memerlukan biaya yang cukup besar. Beberapa orang dari kalangan tertentu mungkin mampu untuk membeli rumah secara tunai pada developer perumahan. Namun, tidak sedikit pula orang yang tidak mampu menyediakan biaya yang besar tersebut untuk membeli rumah yang layak untuk mereka tinggali.

PT. Baiti Sejahtera Pagar Alam adalah sektor yang bergerak dibidang pembangunan perumahan yang dikreditkan, yang berkerjasama dengan Pihak Perantara untuk meringankan beban pembayaran pembelian rumah tersebut. Pihak perantara, yang dalam hal ini adalah bank, akan memberikan Kredit Pemilikan Rumah (KPR) dengan tujuan membantu konsumen yang memerlukan dana untuk dapat memiliki rumah. Bank membayar lebih dahulu biaya pembelian rumah untuk calon konsumen kepada PT. Baiti Sejahtera tersebut, kemudian konsumen akan membayar biaya pembelian rumah tersebut kepada pihak bank dalam jangka waktu tertentu sesuai dengan perjanjian KPR yang telah disepakati antara kedua pihak.

Selama ini, sistem Pendaftaran Pengambilan dan Pengisian Dokumen Formulir data calon kosumen pada PT. Baiti Sejahtera Pagar Alam, sudah terkomputerisasi namun masih menggunakan aplikasi yang sederhana, Prosesnya adalah calon konsumen harus datang sendiri ke PT. Baiti Sejahtera Pagar Alam, dan mengantri jika banyak calon konsumen, dengan Proses ini PT. Baiti Sejahtera Pagar Alam, mengalami banyak kendala seperti lamanya memeriksa data calon konsumen, File-file tidak tersusun rapi, dan calon konsumen merasa dirugikan jika tidak dapat mendaftar padahal sudah lama mengantri` dan lamanya memberikan laporan ke pimpinan, Dalam hal ini Pimpinan PT. Baiti Sejahtera Pagar Alam mengiginkan adanya aplikasi yang dapat membantu proses pendaftaran pengambilan KPR, Tanpa adanya sistem Antrian yang Merugikan Calon konsumen.

Sehubungan dengan hal tersebut maka Peneliti tertarik dengan judul: "Perangkat Lunak Bantu Pendaftaran Kredit Pemilikan Rumah (Kpr) Pada Pt. Baiti Sejahtera Berbasis Web"

Permasalahan yang akan dipecahkan dalam penelitian ini adalah "Bagaimana cara pembuatan Perangkat Lunak Bantu Pendaftaran Kredit Kepemilikan Rumah (KPR) pada PT. Baiti Sejahtera Pagar Alam berbasis Web serta pengolahannya dengan menggunakan PHP dan MySQL ”

Dalam pembuatan Perangkat Lunak Bantu PT. Baiti Sejahtera Pagar Alam, Peneliti membatasi masalah hanya sebatas pada pendaftran type rumah 36 dan type rumah 27 dan buku tamu dengan sederhana. Informasi yang dihasilkan berupa layanan informasi bagi calon komsumen umum dapat mengetahui informasi tentang PT. Baiti 
Sejah Tujuan dari kegiatan ini adalah Membuat suatu Sistem Informasi PT. Baiti Sejahtera Pagar Alam berbasis Web yang dapat menyajikan Blangko pendaftaran, Penelitian bertujuan untuk membuat suatu desain dan implementasi sistem informasi berbasis Web dan pengolahannya., Untuk menyajikan informasi sekilas PT. Baiti Sejahtera Pagar Alam

Manfaat penelitian ini adalah Memberikan pelayanan dan informasi bagi Masyarakat, tentang PT. Baiti Sejahtera Pagar Alam, meningkatkan kemampuan dalam menganalisa setiap masalah yang terjadi, Sebagai acuan dan pembelajaran bagi peneliti lain untuk membuat aplikasi online.

\section{METODOLOGI PENELITIAN}

\subsection{Metodologi Penelitian}

Pressman (2010: 17), menyusun suatu sistem yang baru untuk menggantikan sistem yang lama secara keseluruhan atau memperbaiki sistem yang telah berjalan. Pengembangan sistem ini metode pengembangan menggunakan menggunakan Web Engineering, karena metode ini memberikan ide bagi pengembang maupun user tentang cara sistem akan berfungsi dan yang akan dikembangkan.

\begin{tabular}{lrr}
\multicolumn{1}{c}{ Pengertian } & Rancang & merupakan \\
serangkaian & prosedur & untuk \\
menerjemahkan hasil analisa dari sebuah \\
sistem ke dalam bahasa pemrograman \\
untuk mendepenelitiankan dengan detail \\
bagaimana komponen-komponen & sistem \\
diimplementasikan (Pressman, 2002).
\end{tabular}

Rancangan sistem adalah penentuan proses dan data yang diperlukan oleh sistem baru, perancangan adalah kegiatan yang memiliki tujuan untuk mendesain sistem baru yang dapat menyelesaikan masalah-masalah yang dihadapi perusahaan yang diperoleh dari pemilihan alternatif sistem yang terbaik (Ladjamudin, 2005).

Pengertian bangun atau pembangunan sistem adalah kegiatan menciptakan sistem baru maupun mengganti atau memperbaiki sistem yang telah ada baik secara keseluruhan maupun sebagian (Pressman, 2002). Bangun sistem adalah membangun sistem informasi dan komponen yang didasarkan pada spesifikasi desain (Whitten et al, 2004).

Pengertian rancang bangun merupakan kegiatan menerjemahkan hasil analisa ke dalam bentuk paket perangkat lunak kemudian menciptakan sistem tersebut ataupun memperbaiki sistem yang sudah ada.

HTML merupakan bahasa yang digunakan untuk menulis halaman web. Biasanya mempunyai extensi .htm, .html atau .shtml. Perintah dalam HTML memiliki tag-tag tersendiri yang akan diterjemahkan oleh web browser untuk ditampilkan. Saat ini perkembangan $H T M L$ sudah mencapai HTML 5, bahasa pemrograman ini dikembangkan oleh Tim Bernars Lee pada tahun 1989, web statis pertama pada tahun 1991. Standar dasar HTML telah diatur oleh W3\# Consorsium sebagai berikut:

$<h t m l>$ 
<head>

\section{Depenelitian head}

</head >

$\langle$ body $>$

\section{Isi dokumen}

$</$ body $>$

$</ h t m l>$

Komponen standar di atas harus ada dalam setiap penggunaan HTML (Suyanto, 2009:83).

Secara teknis, Internet atau International Networking merupakan dua komputer atau lebih yang saling berhubungan membentuk jaringan komputer hingga meliputi jutaan komputer di dunia (internasional), yang saling berinteraksi dan bertukar informasi. Sedangkan dari segi ilmu pengetahuan, Internet merupakan sebuah perpustakaan besar yang didalamnya terdapat jutaan (bahkan milyaran) informasi atau data yang dapat berupa text, graphic, audio maupun animasi, dan lain-lain dalam bentuk media elektronik. Orang bisa "berkunjung" ke perpustakaan tersebut kapan saja dan dari mana saja. Dari segi komunikasi, Internet adalah sarana yang sangat efisien dan efektif untuk melakukan pertukaran informasi jarak jauh, maupun di dalam lingkungan perkantoran.

Apabila kita perhatikan perkembangan pada saat ini dari segi penggunaan. Internet berperan sebagai sumber informasi, juga sebagai tempat main games online dan lain sebagainya.
Kemajuan teknologi internet, ibarat satu pisau bermata dua yang akan membuat kita maju. Disisi lain mendorong kita terjerumus pada hal-hal yang negatif. Contoh positif antara lain;

1. Banyak situs-situs yang siap mendidik kita tentang ilmu pengetahuan baik bidang komputer, atau pendidikan lainnya yang bersifat online. Sebagai contoh: http://www.ilmukomputer.com, http://www.edukasi.net dan lainnya.

2. Forum-forum tempat kita berdiskusi tentang suatu masalah yang sesuai dengan kelompok ilmu tertentu. Contoh indowli@yahoogroup.com (merupakan tempat berdiskusi tentang jaringan wirelles indonesia).

Selain kedua contoh di atas, masih terdapat situs-situs lain yang mendidik bagi kita, sehingga kita perlu memilahdan memilih situs yang mendidik dan tidak mendidik kita.

PHP adalah sebuah bahasa scripting yang dibundel dengan $H T M L$, yang dijalankan di sisi server. Sebagian perintahnya berasal dari C, Java, dan Perl dengan beberapa tambahan fungsi khusus PHP. PHP dimaksudkan untuk mengganti teknologi lama seperti CGI (Common Gateway Interface). PHP bisa berinteraksi dengan hampir seluruh teknologi web yang sudah ada, fleksibilitas ini sangat bermanfaat bagi perusahaan-perusahaan yang besar dan sibuk.

PHP ditulis oleh Rasmus Lerdorf yang pada awalnya ia gunakan untuk mencatat jumlah pengunjung situs yang membuka 
halaman resumenya. Ia kemudian menulis ulang kode-kodenya dengan bahasa $\mathrm{C}$ yang kemudian menjadikan bahasa itu menjadi lebih kaya kemampuan. Barulah setelah itu banyak bermunculan tokoh-tokoh yang berjasa dalam perkembangan $P H P$ seperti Zeev Suraski dan Andi Gutmans yang menulis kembali parsing Engine unuk menciptakan $P H P$ versi 3. $P H P$ kemudian menjadi modul Apache yang paling sering digunakan (Suryanto, 2009:88).

Website dapat diartikan sebagai layanan di dalam jaringan internet yang berupa ruang informasi berupa teks, gambar dan program multimedia lainya berupa animasi, suara, dan atau gabungan dari semua itu, baik yang bersifat statis maupun dinamis yang membentuk satu rangkaian bangunan yang saling terkait antara satu halaman dengan halaman lain yang sering disebut sebagai hyperlink (Budi Raharjo, 2011:2).

Unified Modelling Language adalah keluarga notasi grafis yang didukung oleh meta-model tunggal, yang membantu pendepenelitianan dan desain perangkat lunak, khususnya sistem yang dibangun menggunakan pemrograman berorientasi objek (Munawar:40:2005).

\subsection{Analisa Rekayasa Web}

\subsubsection{Sistem yang sedang berjalan}

Pada sistem yang saat ini sedang berjalan, pemohon langsung datang ke tempat pendaftaran lalu melakukan pendaftaran, mengisi formulir dan melengkapi berkas dengan staf bagian pendaftaran. Jika digambarkan maka use case diagram sistem yang sedang berjalan sebagai berikut:

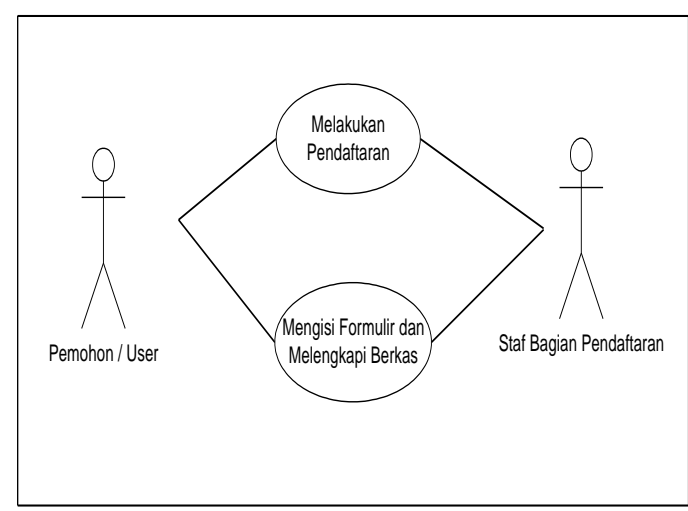

Gambar 1.Sistem Berjalan

\subsubsection{Sistem Usulan}

Untuk merancang sistem yang akan diusulkan dalam penelitian ini, penulis menggunakan use case diagram untuk mempermudah dalam menjelaskan rancangan sistem. Aktor yang akan digunakan adalah admin dan user yang akan berinteraksi melalui sarana web. Untuk lebih jelasnya perhatikan gambar di bawah ini:

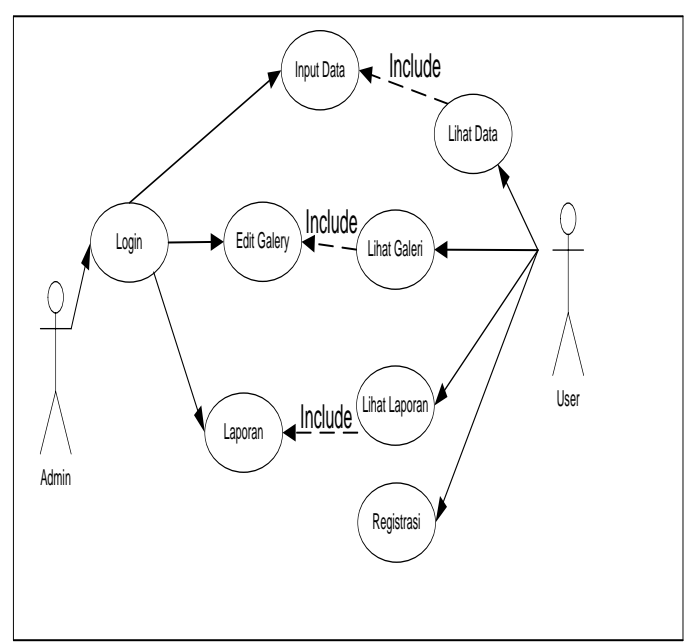

Gambar 2. Sistem Usulan 


\subsection{Rancangan Website}

\subsubsection{Rancangan Menu Utama}

Rancangan menu utama merupakan indek dari web yang akan dikembangkan, halaman inilah yang akan terlebih dahulu berhadapan dengan user. Adapun rencana tampilan halaman utama sebagai berikut :

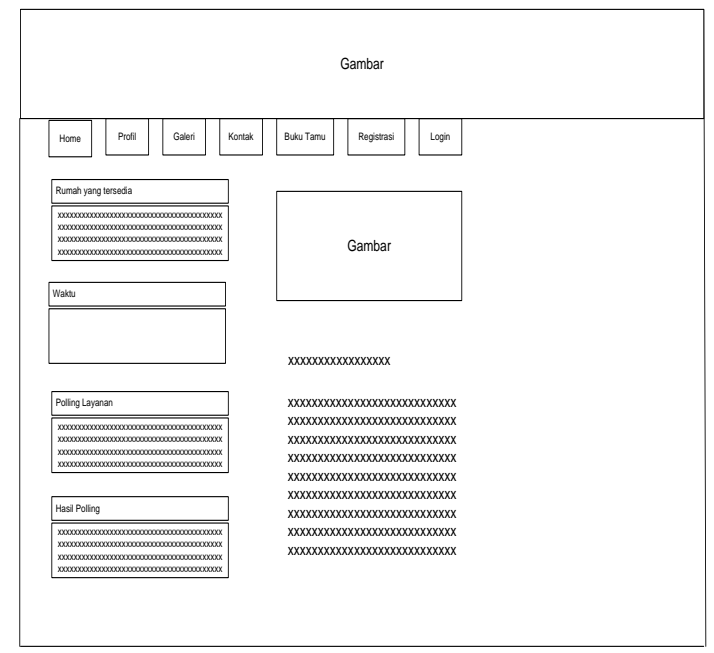

Gambar 3.Rancangan Menu Utama

\subsubsection{Rancangan Halaman Galeri}

Rancangan Halaman galeri Perangkat Lunak Bantu Pendaftaran Kredit Pemilikan Rumah (KPR) Pada Pt. Baiti Sejahtera Berbasis Web ini adalah output dari input galery yang dilakukan oleh admin. Rancangan halaman galeri dapat kita lihat seperti gambar dibawah ini:

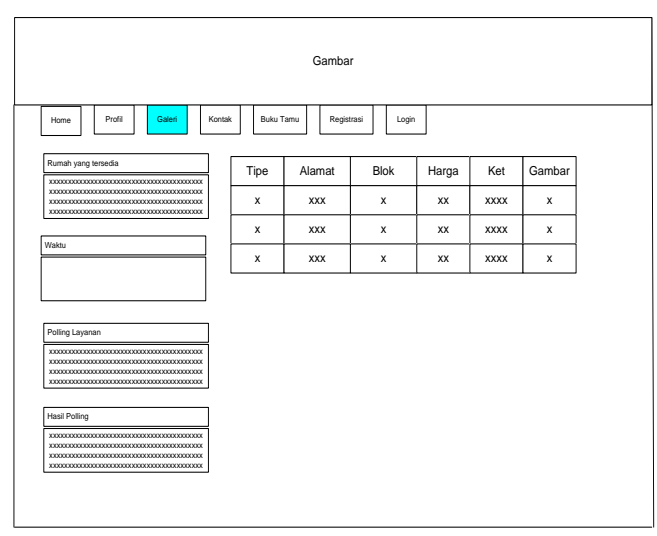

Gambar4.Rancangan Halaman Galeri

\subsubsection{Rancangan Halaman Registrasi}

Rancangan Halaman registrasi Perangkat Lunak Bantu Pendaftaran Kredit Pemilikan Rumah (KPR) Pada Pt. Baiti Sejahtera Berbasis Web ini untuk user yang ingin registrasi. Rancangan halaman registrasi dapat kita lihat seperti gambar dibawah ini :

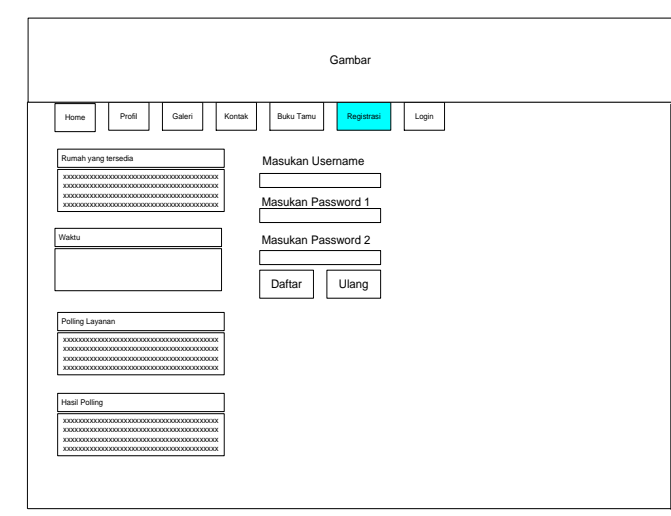

Gambar 5.Rancangan Halaman Registrasi

\subsubsection{Rancangan Halaman Buku Tamu}

Rancangan Halaman Buku Tamu pada Perangkat Lunak Bantu Pendaftaran Kredit Pemilikan Rumah (KPR) Pada Pt. Baiti Sejahtera Berbasis Web ini adalah tempat user memberikan saran, masukan dll. Rancangan halaman buku tamu dapat kita lihat seperti gambar dibawah ini :

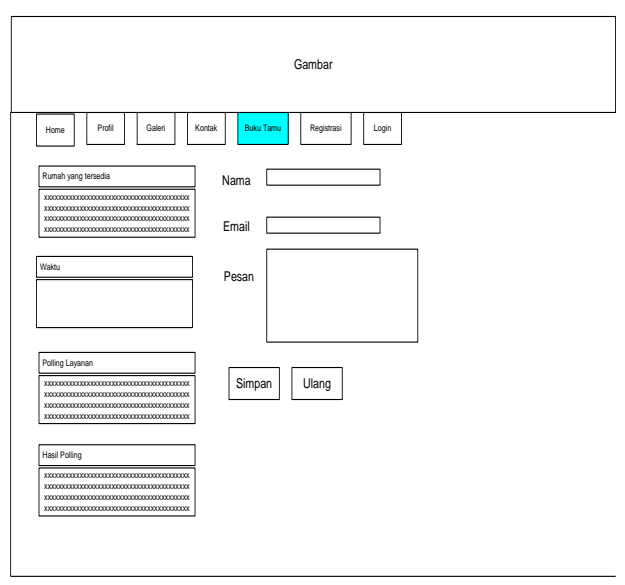

Gambar 6. Halaman Buku Tamu 


\subsection{Squency Diagram Admin}

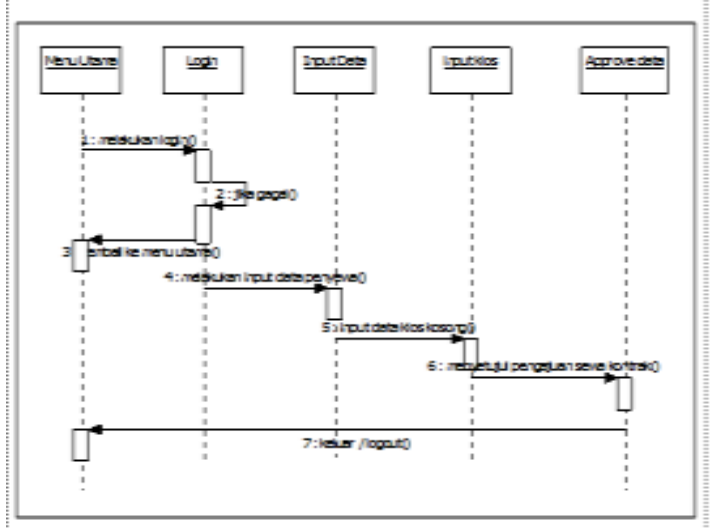

Gambar 7. Squency Diagram Admin

\subsection{Squency Diagram User}

Menggambarakan Intraksi antara user dengan sistem di sini user panggil menu web maka sistem menampilkan home user kemudian user mencari dan melihat data. jika tidak ada user ,akan keluar dari web.

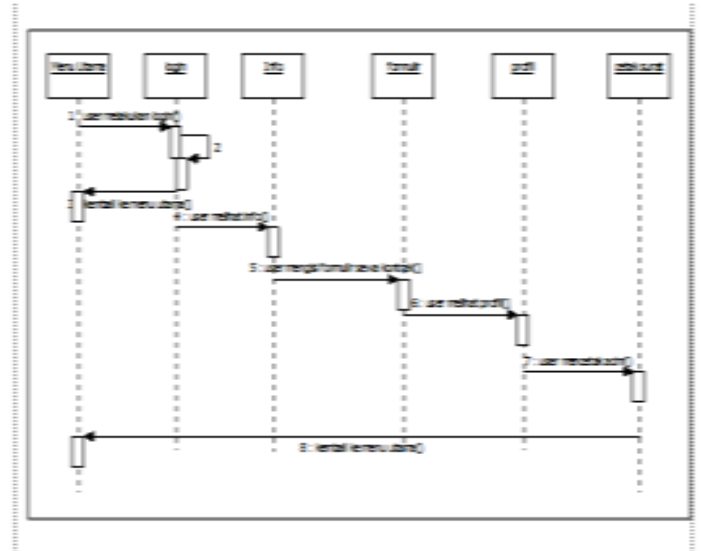

Gambar 8.Squency User User

\subsection{Class Diagram Admin}

Class diagram menggambarkan struktur dan deksripsi class, package dan object serta hubungan satu sama lain. Class diagram terdiri dari relasi beberapa class, dalam class itu sendiri terdiri dari atributte dan operation yang menggambarkan keadaan suatu sistem yang menawarkan layanan untuk memanipulasi

keadaan

tersebut

(metoda/fungsi).

\subsection{Rancangan Halaman Menu Utama}

Rancangan Halaman utama merupakan halaman awal yang ditampilkan pada saat user membuka Website. Tampilan halaman utama dapat dilihat pada Gambar di bawah ini:

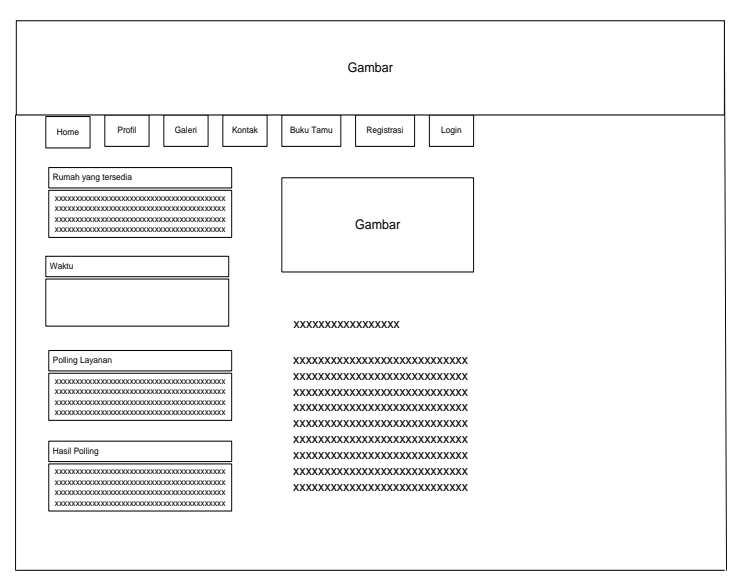

Gambar 9. Rancangan Tampilan Halaman Utama

\section{HASIL DAN PEMBAHASAN}

\subsection{Hasil}

website Perangkat Lunak Bantu Pendaftaran Kredit Pemilikan Rumah Pada PT. Baiti Sejahtera Kota Pagar Alam. dari halaman ini kita dapat memasuki halaman home, Profil, galeri, Kontak, Buku Tamu, Daftar dan Login:

\subsubsection{Halaman Login}

Halaman Login adalah halaman yang digunakan user dan admin untuk masuk kedalam halaman mereka masing-masing, halaman login yang dapat dilihat pada gambar di bawah ini: 


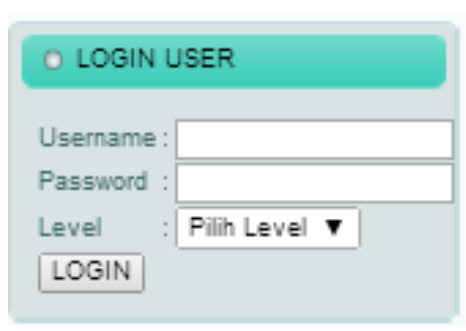

Gambar 10. Halaman Login

\subsubsection{Menu Utama}

Menu utama adalah tampilan awal ketika kita membuka WebsiteBadan Kepegawaian Daerah Kota Pagar Alam yang terdiri dari menu home, profil, informasi,berita,galeri dan buku tamu yang dapat dilihat pada gambar 16 dibawah ini:

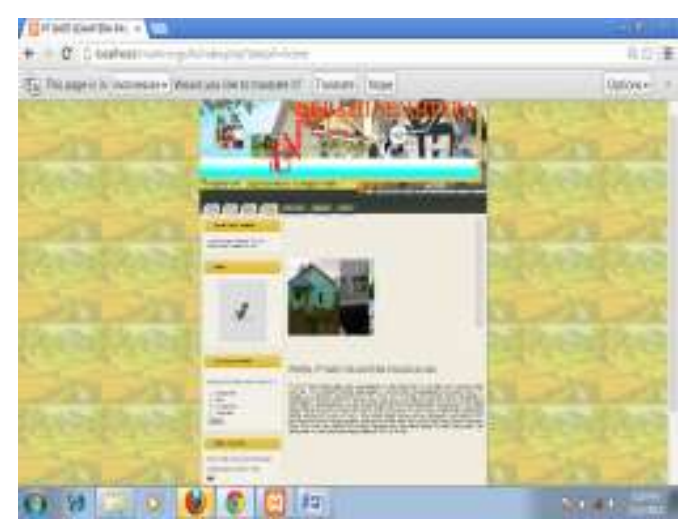

Gambar 11. Menu Utama

\subsubsection{Halaman Admin}

Halaman Admin untuk mengelola data seperti input data dan lihat data. Halaman admin dapat kita lihat seperti gambar dibawah ini :

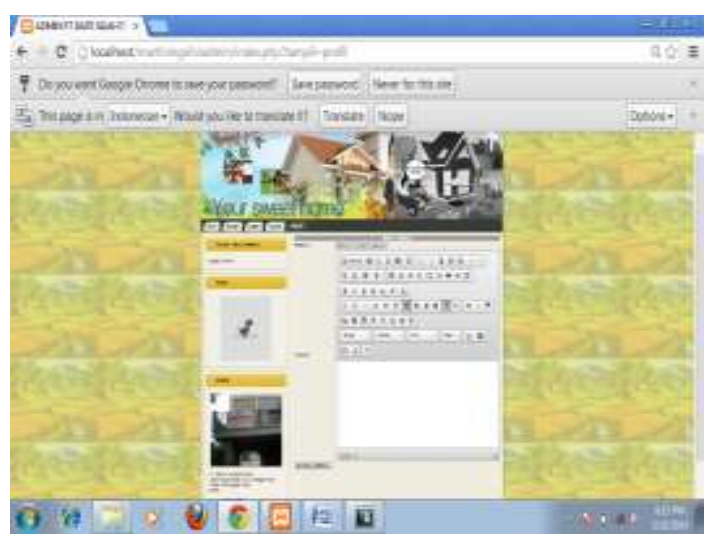

Gambar 12. Halaman Admin

\subsubsection{Menu Admin Input Galeri rumah}

Halaman ini digunakan untuk penginputan data rumah di sistem website Perangkat Lunak Bantu Pendaftaran Kredit Pemilikan Rumah Pada PT. Baiti Sejahtera Kota Pagar Alam, penginputan data rumah ini dilakukan oleh admin setelah admin masuk kesistem.

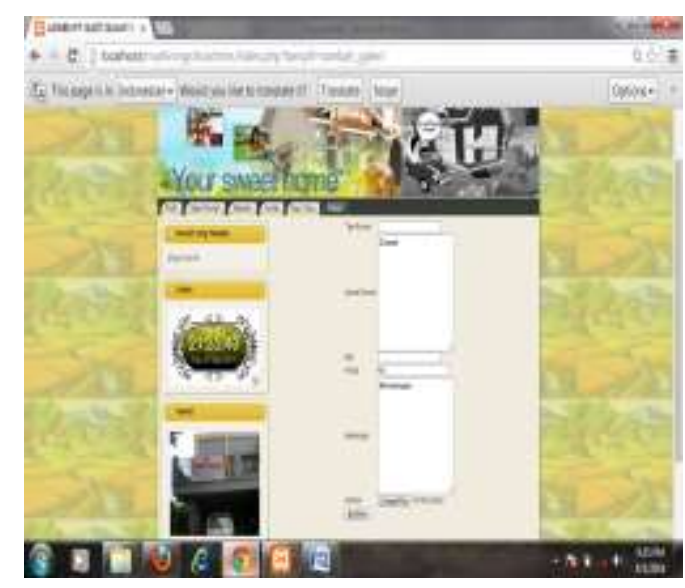

Gambar 13.Menu Admin Input data Profil

\subsubsection{Menu Admin Input Kontak}

Halaman ini digunakan untuk penginputan kontak di website Perangkat Lunak Bantu Pendaftaran Kredit Pemilikan Rumah Pada PT. Baiti Sejahtera Kota Pagar Alam, penginputan kontak ini dilakukan oleh admin kesistem. Halaman nantinya dapat di gunakan oleh user untuk mengakses fasilitas yang di sediakan oleh 
website Perangkat Lunak Bantu Pendaftaran Kredit Pemilikan Rumah Pada PT. Baiti Sejahtera Kota Pagar Alam.

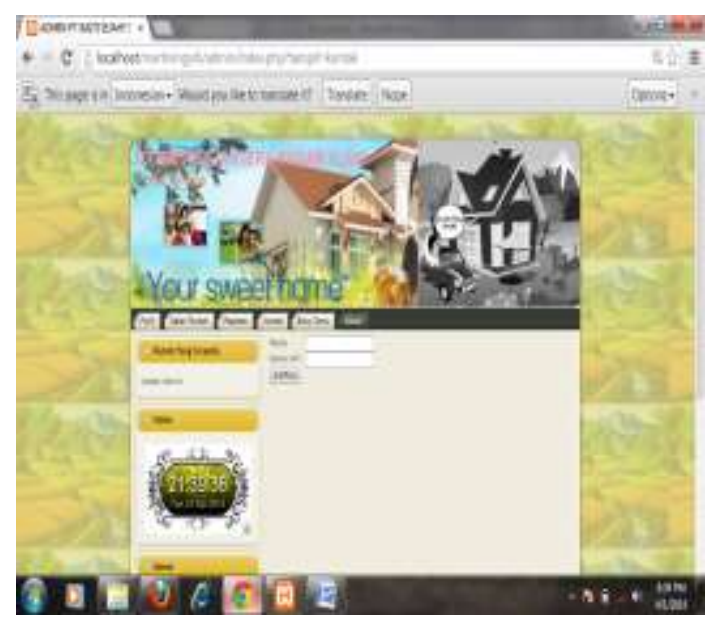

Gambar 14. Menu Admin Input Kontak

\subsubsection{Halaman Input Profil}

Halaman ini digunakan untuk penginputan profil di website Perangkat Lunak Bantu Pendaftaran Kredit Pemilikan Rumah Pada PT. Baiti Sejahtera Kota Pagar Alam, penginputan profil ini dilakukan oleh admin kesistem. Halaman input profil di website Perangkat Lunak Bantu Pendaftaran Kredit Pemilikan Rumah Pada PT. Baiti Sejahtera Kota Pagar Alam dapat kita lihat seperti gambar dibawah ini :

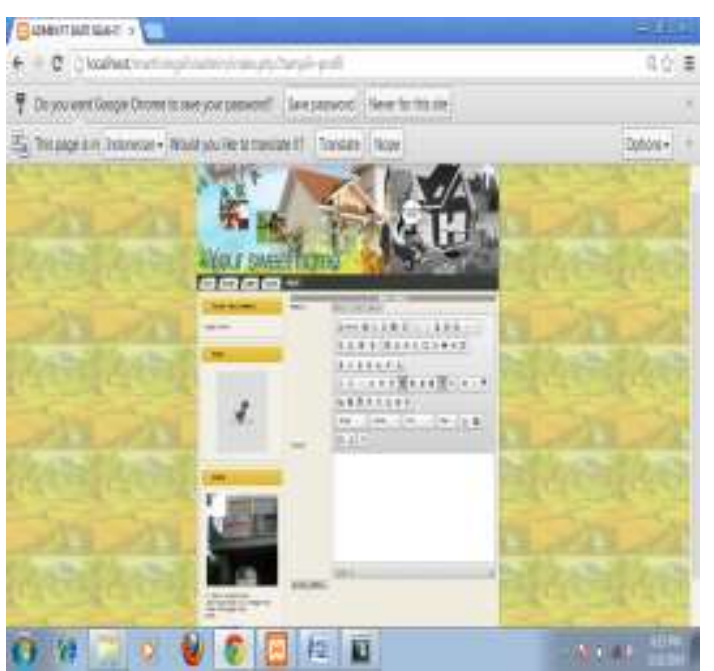

Gambar 15. Halaman Input Profil

\subsubsection{Halaman Output Galeri}

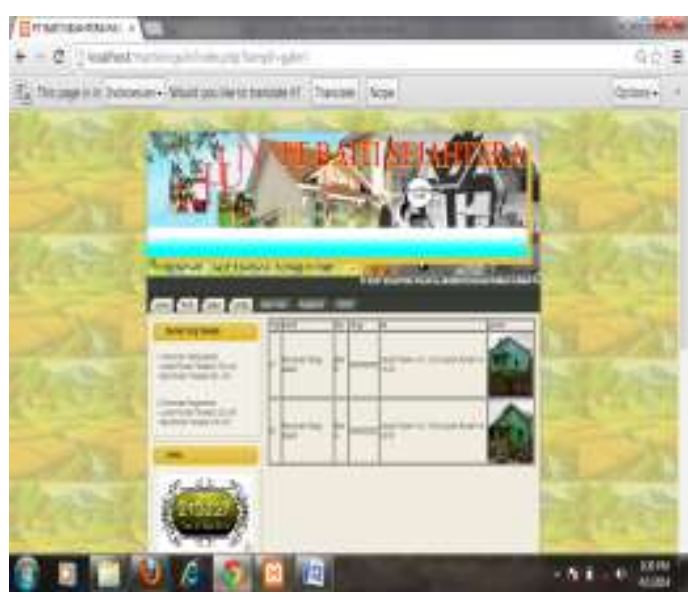

Gambar 16. Halaman Output Galeri

\subsubsection{Halaman Output Kontak}

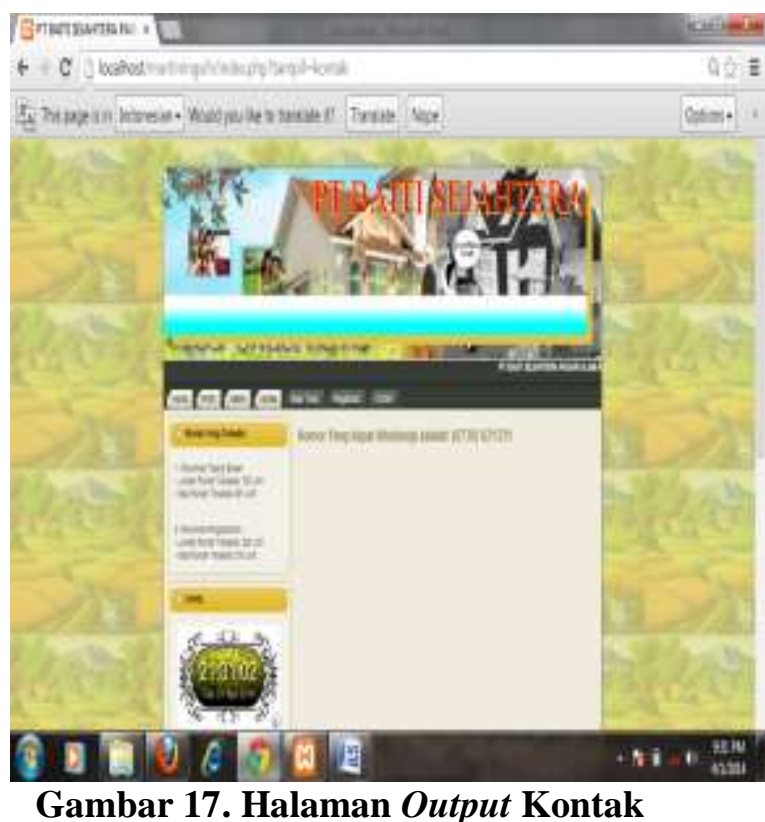
3.1.8. Halaman
Data
Pemohon

Berpenghasilan Tidak Tetap 


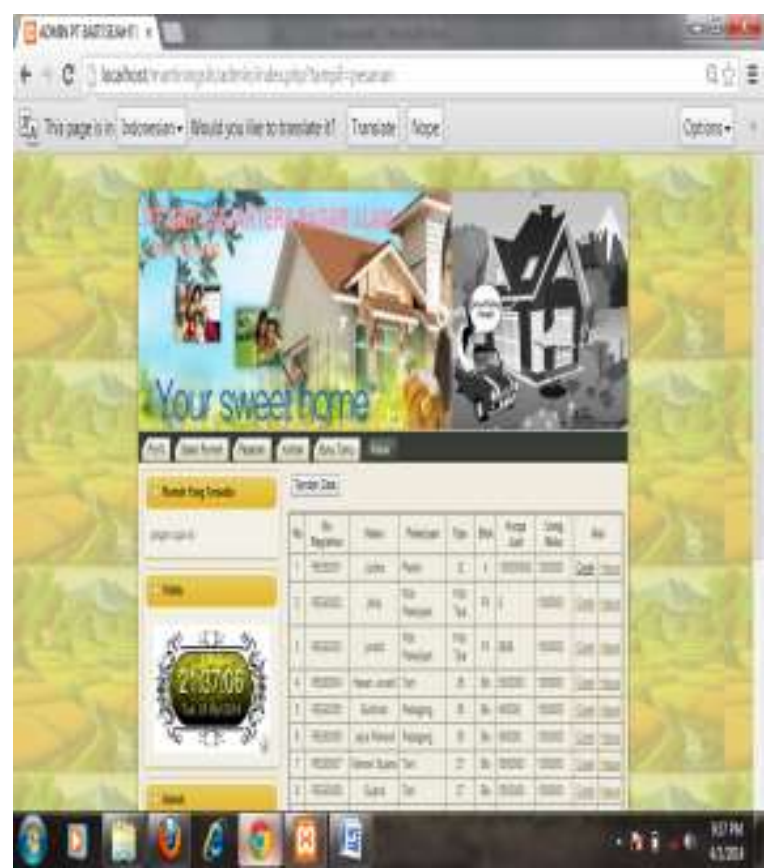

Gambar 18. Halaman Data Pemohon

Berpenghasilan Tidak Tetap

\section{KESIMPULAN}

Berdasarkan dari hasil penelitian yang telah dilakukan, maka peneliti menyimpulkan bahwa:

1. Dengan adanya perangkat lunak bantu pendaftaran kredit pemilikan rumah pada PT. BAITI SEJAHTERA Kota Pagar Alam Berbasis WEB. pelanggan dapat meminimalisir waktu karena pelanggan dapat memesan rumah kredit dimanapun dan kapanpun.

2. Dengan menggunakan perangkat lunak bahasa pemrograman Web dapat memberikan laporan penjualan yang tepat cepat dan akurat.

3. Aplikasi Web ini merupakan tambahan promosi penjualan rumah kredit pada PT. BAITI SEJAHTERA Kota Pagar Alam.
4. Aplikasi Web ini admin dapat dengan mudah dalam memberikan laporan penjualan.

Dari kesimpulan diatas, perangkat lunak bantu pendaftaran kredit pemilikan rumah pada PT. BAITI SEJAHTERA Kota Pagar Alam Berbasis WEB akan lebih efektif dan efisien serta tidak menghabiskan waktu yang lama.

\section{DAFTAR RUJUKAN}

Ladjamudin. 2005. Analisis dan Desain Sistem Informasi. Yogyakarta : Graha Ilmu.

Peranginangin, Kasiman. 2006. Aplikasi Web dengan PHP dan MySQL. Yogyakarta : Andi.

Pressman RS. 2002. Rekayasa Perangkat Lunak Pendekatan Praktisi (Buku Satu). Yogyakarta: Andi.

Sumarta, T. Perancangan Model Berorientasi Objek Menggunakan Unified Modeling Language(UML) Studi Kasus Sistem Pengolahan Parkir Pada PT. TRIKARYA ABADI. diunduh dari http://gunadarma.ac.id Tanggal 1 Desember 2013.

Suryanto, Asep Herman. 2009. Step by Step Web Design: Theory ang Practices. Yogyakarta: Penerbit Andi

Whitten JL et.All. 2004. System Analysis and Design Methods. Diterjemahkan oleh: Tim Penerjemah Andi. Yogyakarta: Andi. 